\title{
A critical discourse analysis of headlines in online news portals
}

\author{
Glorilyn M. Montejo ${ }^{1 *}$, Teresita Q. Adriano ${ }^{2}$ \\ ${ }^{1,2}$ Department of Education, University of Immaculate Conception, Davao City, Philippines
}

\author{
Keywords \\ Applied linguistics \\ Headlines \\ Discursive devices \\ Critical discourse analysis \\ Ideologies \\ Sensational \\ Online news portals \\ Philippines
}

Received: 14 February 2018

Accepted: 22 March 2018

Published: 18 April 2018

\begin{abstract}
This study aimed to determine the discursive devices used in the news headlines, unravel the ideologies of the media practitioners, and reveal the insights that can be generated from the findings. Thirty headlines were gathered from five major online news portals in the Philippines: ABS-CBN, CNN Philippines, GMA, Interaksyon, and Rappler. This is a qualitative study that is seen from Fairclough's Critical Discourse Analysis (CDA) in 1995. Results showed ten discursive devices used in the headlines by media practitioners to attract attention from readers that may direct them to read the headline and read the entire article. It was also found out that the devices brought out media practitioners' ideologies. It was further found that writers or editors were objective or neutral, subjective or biased, and misleading. The selection of the words used in the headlines showed the political dispositions of the news practitioners who intentionally choose only those speeches or news that may create sensational feelings among the readers. The writer or editor's judgment angle reflected how he or she wanted the readers to perceive the issue. Furthermore, the results of this study may provide ideas to news consumers to not just read the headlines but read the entire article so that they may know if the headline matches its content and that they may be able to identify if the issue is true or not if it is slanted or sensationalized.
\end{abstract}

\section{INTRODUCTION}

Everyone at some point is exposed to and has read daily news headlines in the online news portals, especially now that the use of internet and its content have rapidly grown. In the world of media, headlines are as important part of the news as titles are of any books or essays. They are often the most important element on pages as they give readers an overall picture of the news and through them, readers may determine whether to read the entire article. The words used in the headline present the article's content, attract the attention of the readers and create interest in the story, and, at the same time, show the hidden meanings behind the words and phrases used by writers.

However, in some media outlets, headline editors summarize the article through customizing reporters' news headlines in social media which have been in question. Most often, writers use discursive devices which may exaggerate the message of the headlines just so the articles may be read. oftentimes, readers are dismayed for when they read the entire article, the headline does not match the content. Instead, writers intentionally sensationalize the news to catch the readers' attention (Grabe, Zhou, \& Barnett, 2001; Oetomo, lestariningsih, \& Susanti, 2017).

Furthermore, news headlines have recently received increasing research attention from a variety of disciplines including linguistics, sociolinguistics, pragmatics, journalism, and experimental psychology. In Brandenstein (1911) in his study on sensational and political headlines revealed that majority of all political news content is more often of a sensational nature as compared to other types of headlines. While $75 \%$ of all political headlines where coded as sensational, the ratio of political sensationalism to other headlines was much lower at only $33 \%$, and in the overall content, the level of sensational non-political headlines to non-

\footnotetext{
* corresponding author: Glorilyn M. Montejo

†email: montejoglorilyn@gmail.com
} 
sensational political headlines in aggregate was 39\%. In Pakistan, Javed and Mahmood (2011) in their study on News Headlines of Budget of Pakistan in 2011 to 2012 conclude that though editors claim to give purely neutral information, it was found out that headlines are representations of their ideologies regarding their political predispositions. It was further found out that the newspaper headlines not only show graphological and general rhetorical features but certain unseen ideologies of the editors are depicted behind the apparently simple statements they have written.

In the same vein, the study of Yasmeen, Mahmood, Mahmood, Shakir, and Sattar (2014) on headlines newsworthiness in both English and Urdu newspaper in Pakistan discovered that in the construction of newspaper headlines, ideology works. Different ideologies are working behind these seemingly simple words besides revealing the universal metaphorical and graphological characteristics of these headlines.

In Ghana, Bonyadi and Samuel (2013) explored the two newspapers' kind of textual and rhetorical strategies implemented to proliferate ideologies. Results showed that the headlines are used by the two newspapers to draw attention to the main stories. Similarly, the subjective approach of the journalists influenced the way how they present and write news headlines using several forms of rhetorical strategies, such as irony, parallelisms, antithesis, and puns.

In the Philippines, Metila (2013) found that headlines displayed different framing for the involved groups of subjects. The result revealed that in exaggerating the violence and impact of the event, the figures and exaggerated word choice were used. The inaccurate use of references to the event location highlighted news importance over accuracy. Nowadays, hearsays on media bias are widespread and that media practitioners try to attract the readers with its headlines. Many of the readers exaggerate their comments and reaction on issues as revealed by headlines. This is the reason why I become interested to focus on this area of research. Also, in the wider field, there have been several studies of well-documented critical discourse analysis on media like newsworthiness in newspaper, discourse of television news program, and news framing. Yet, little attention, especially in the Philippines, has been given to headlines in the online news portals. This study investigated thirty headlines from five popular online news portals in the Philippines namely ABS-CBN, CNN Philippines, GMA, Interaksyon, and Rappler. Moreover, this study is delimited to discovering the discursive devices found in the news headlines, identifying the ideologies of the media practitioners reflected in the headlines, and revealing the insights that can be generated from the findings.

Furthermore, the findings of this study may benefit the media practitioners like journalists, writers, and editors that they may use the words in the headlines that would truly reflect its content. This study may also be beneficial to online news viewers or readers by reading closely its contents rather than reading only its headlines. This may help them understand the whole story or the issue better. In addition, this study may also help language teachers to teach students critical reading so that they may critically understand the hidden meaning behind every text they read.

\section{Purpose of the Study}

The purpose of this study was to determine the discursive devices found in the news headlines, discover the ideologies of the media practitioners reflected in the headlines, and reveal the insights that can be generated from the findings. This study investigated thirty headlines from five popular online news portals in the Philippines namely ABSCBN, CNN Philippines, GMA, Interaksyon, and Rappler.

\section{Research Questions}

1. What are the discursive devices found in the headlines?

2. What are the ideologies of media practitioners reflected in the headlines?

3. What insights can be generated from the findings?

\section{Theoretical Lens}

This study is seen through the standpoint of Critical Discourse Analysis (CDA) by Fairclough and Wodak (1995). He asserted that in the context of both written and spoken discourse, CDA can be employed to describe, interpret, and explain the language and power. It lays its focus on discourse and society. It aims to look at not only the text itself but also its production and interpretation within a larger social context. Any instance of discourse is simultaneously a threedimensional phenomenon: an instance of written and spoken text, an instance of discourse practice, and an instance of social practice. The first dimension of discourse relates to language analysis or text analysis. It focuses on certain features of texts, such as evaluative language, vocabulary, intensification and quantification, immediacy, reference to emotion, reference to elite people, role labels and institutional agents/agency, country, and events.

Discursive practices or discourse practices are processes of text production, distribution, and consumption. They refer to the activity of reading a text and understanding it by relating it to its context (Conboy, 2013; Kang \& Ogawa, 2017). Social practices refer to the relation between discourse and social institutions and organizations. Fairclough 
(1992) points out that the social practice dimension attends to the issues of concern in social analysis, such as the institutional and organizational circumstances of the discursive event and how that shapes the nature of the discursive practice, and the constitutive/constructive effects of discourse. Hence, it brings out or unravels ideologies expressed in discourse revealing how power structures are constructed in through discourse. In other words, it explores how language is regarded as not something neutral or transparent. Furthermore, this study utilized the discursive or sensationalizing devices characterized by (Molek-Kozakowska, 2013). She categorizes these devices into ten: evaluative language, vocabulary, intensification and quantification, immediacy, reference to emotion, reference to elite people, role labels, institutional country, agency, and events.

\section{LITERATURE REVIEW}

News headlines are the most significant portion of the news for they deliver a fast mode of information to those who have no time to read the complete details of news item (Javed \& Mahmood, 2011). Also, Reah (2002)defines headline as a type of text that is unique which consists of a series of functions that precisely dictate its content, shape, and structure. It also functions within a range of restraints that limit the liberty of the journalist in writing. In general, a headline summarizes the entire story of the news. Only the key idea of the entire news story is written as the headline. Importantly, headlines can be recognized by their placement. That is, headlines are, at all times, placed overhead the news story. And besides encapsulating the news story, headlines are accountable for distracting and catching the attention of the people (Prateepchaikul, 2010).

Furthermore, Javed and Mahmood (2011) state that headlines act as a precursor to the news reports. That is, readers read first the headline before they read the entire news story. Moreover, Conboy (2013) states that headlines serve 3 vital functions. First, they offer a short summary of the main news to the readers; hence, there's no need for the readers to read the complete story to capture the point. Second, they entice attention. Headlines divert people's attention by various font sizes and through the use of vocabulary. Third, they frequently offer an initial indicator of the style and content of the news values of the newspaper. This is an important way in which the newspaper appeals to its audience. He also added that it is the headline that does the job in reinforcing the way things are through the language of the news.

The language used to create the headline is possibly hardly found in other forms of text types. Vocabulary is the most outstanding feature of the language of headlines. The vocabulary being used in a headline needs to fit the spaces. Typically, it is short, yet it should catch attention and must be effective. As Fairclough (1992) notes, headlines are written to take hold of the attention of the news consumers. He further observed that some readers of news never make it past the headline and that it is regrettable. Some consumers of the news think that the whole story has been boiled down to that bold print and because of this reason, the making of the biased headlines affects public opinion and perception. CDA is a procedure of Discourse Analysis that exposes the way discourses are used every day for meaning, power relations, and expansion of new information. Words, whether written or spoken, have control (Luke, Freebody, et al., 1997). According to Tannen, Hamilton, and Schiffrin (2015), it is concerned with analyzing and studying words used in discourses to make public the source of power, dominance, inequality and bias, abuse, and how these sources started, reproduced, maintained, and transformed within specific economic, social, political, and historical contexts. In Fairclough (1992)s, particularly Fairclough and Wodak (1995), developed one of the most dominant approaches for analyzing discourse and thereafter, it has been revisited in several publications making it (Fairclough \& Wodak, 1995; Fairclough, 1992, 2001) as well as Fairclough (2001). The method of Fairclough is based on the conception that the way individuals produce and construe language is ultimately affected and regulated by power. Fairclough (1992) expounds it through the following processes: how people produce and deduce language is affected by their experiences of the world, and experiences are influenced by social organization, which, in turn, is affected and governed by power. In other words, power commands to a considerable degree how the world works, for example, the news is formed by commercialism and business interests, which, in turn, affects the experiences one had similar to the experience of what reading news articles is like, and the experiences affect the aspects of language use, for instance, which point of view of an event is noticeable in everyday discussions.

Moreover, Fairclough (2001) said that how a text is produced or interpreted is dependent on the nature of the sociocultural practice in which the discourse is a part of. The discourse practice of text's nature forms text, and leaves hints in surface features of the text. To be precise, the actual textual features and choices of the writer in terms of lexis and structure of the text are traces of the discourse practice, which, in turn, is controlled by sociocultural practices. In other words, structures and practices of the social 
sphere affect the ways in which texts are generated, allocated, and interpreted, and, additionally, through influencing how texts are created and interpreted, social structures are in a way encrypted in the features of the text. Consequently, it is the discursive or sensationalizing devices of the text on which the investigation in this study will mainly be based.

Furthermore, Van Dijk (2013) explains that frequently, the ideological impact of discourse is indirect. Ideologies influence social attitudes which may sway the individual opinions of group representatives represented by the mental models of specific persons and events. Mental models with ideologies thus control the sense produced in text and talk, and discourse about such events. When people perform a discourse, they may be able to form biased models based on their ideologies. Therefore, various individual social members may have different ideological comprehensions. This is one of the reasons for the variable nature of discourse understanding and interpretation.

\section{METHODOLOGY}

The data of this study, which were the news headlines, were taken from the websites of the online news portals of ABSCBN, CNN Philippines, GMA, Interaksyon, and Rappler. The thirty headlines were collected randomly from November 2015 to February 2017. There was no letter of permission sent to the identified networks since the data were collected from their online websites posted for public viewing. The posting gives any viewer the permission to grab and use the data for research purposes. Furthermore, all the news headlines collected are appended in the appendices for ethical consideration.

After the collection of data, which were the thirty headlines from the five major online news portals, such as ABS-CBN, CNN Philippines, GMA, interaksyon, and Rappler, I looked into each headline and grouped them according to the discursive devices found in them. These are evaluative language, vocabulary, intensification and quantification, immediacy, reference to emotion, reference to elite people, role labels, institutional agents/agency, country, and events.

Furthermore, since each of these headlines used two or more discursive devices, I thoroughly looked into the eye catching words or phrases or emotive vocabulary used by the writers or editors to evoke the readers' feelings and attention that would lead them to read the entire article.
Then, I discussed the deeper meanings and uses of each of these words or phrases found in the headlines. Moreover, because of these words, phrases, or devices used by the media practitioners, their ideologies are unraveled. I decisively discussed these ideologies of media practitioners that are reflected in the headlines by using the Critical Discourse Analysis approach of Fairclough and Wodak (1995). After all the results were revealed, insights were generalized based on them. In addition, in order to ensure the soundness of the findings of this study, peer debriefing was done. I asked two experts in Applied Linguistics, specifically in Critical Discourse Analysis, to countercheck my analysis. I met with these two experts to discuss with them their comments and observations for the improvement of this study. Then, I underwent a revision based on their logical and intellectual suggestions.

\section{RESULTS AND DISCUSSION}

Discursive devices in this study refer to the language instruments that play key roles in making the headlines attractive, catchy, and influential. The best headlines both sell and tell; specifically, they tell the consumers instantaneously what the news is all about and persuade them that the story is worth reading (Duzett, 2011). Generally, headlines are read first and the information expressed is used strategically by the editors or headline writers; thus, to make it happen, they use discursive devices in their headlines to catch the readers' curiosity and capture the significance of the story (Pajunen, 2008). In this study, the headlines are gathered with respect to these discursive devices that are analyzed through Critical Discourse Analysis. Media discourse is a text that is not simple. One cannot comprehend it easily because even if the text appears to be simple but the apparently simple text conveys very confusing meanings, especially in this study where the focus is the news headlines. Hence, the use of CDA is applied here.

Illustrated in Table 1 are the discursive devices used in the headlines that are used to attract the attention of the readers. These are evaluative language, vocabulary, intensification and quantification, immediacy, reference to emotion, reference to elite people, role labels, and institutional agency and events.

Headline 1, Anti-Duterte ad causes uproar online, has three discursive devices found in it. These are evaluative language, negative vocabulary, and immediacy. H1, H2, H3 
TABLE 1. Discursive devices found in the headlines

\begin{tabular}{lrllll}
\hline \hline Headlines & & \multicolumn{2}{l}{ Discursive Devices } & Headlines & Discursive Devices \\
\hline H1: Anti-Duterte & ad & $\begin{array}{l}\text { Evaluative Language } \\
\text { (causal relation), Vocabu- }\end{array}$ & $\begin{array}{l}\text { H8 Dev't aid 'highest } \\
\text { ever' under Duterte }\end{array}$ & $\begin{array}{l}\text { Evaluative Language (Su- } \\
\text { perlative) and Reference to }\end{array}$ \\
causes uproar online & lary, and Immediacy & $\begin{array}{l}\text { Dominguez Source: Rap- } \\
\text { pler, January 15, 2017 }\end{array}$ & Elite People \\
Source: ABS-CBN News, & & &
\end{tabular}

H2: Bong Go "knocks out" Pacquiao Source: ABS-CBN News, Dec.15, 2016

H3: Drilon fears 3-B aid from West put in jeopardy over Duterte 'insults' Source: GMA, October 12, 2016

H4 Duterte: Binay and his family will go to jail if he fails Source: CNN Philippines, April 9, 2016

H5 China may give Filipino fishermen access to Scarborough Source: ABS-CBN News, Oct. 18, 2016

H6 Duterte: Obama must listen to me on human rights Source: CNN Philippines, August 31, 2016

H7 Economist: govt should focus on crops other than rice Source: Interaksyon, Jan. 23, 2017

H15 Some 800,000 devotees join fluvial parade for Cebu's Sinulog Festival Source: GMA, January 15, 2017

H16 Advocacy group urges Duterte to sign anti-smoking EO soonest Source: GMA, January 15, 2017

H17 Duterte eyeing visit to Vatican because of 'pope joke,' spokesman says Source: GMA, May 11, 2016
Evaluative Language (Ambiguity), immediacy and Reference to Elite People

Evaluative Language (Numerical), immediacy, vocabulary, and Reference to Elite People

Evaluative Language (Epistemic Modality) and Reference Elite People

Evaluative Language (Epistemic Modality) and Reference to Role Label

Evaluative Language (Deontic Modality) and Reference to Elite People

Evaluative Language (Deontic Modality) and Reference to Role Label

Quantification, Immediacy and Reference to Event

Immediacy, Intensification and Reference to Elite People

Immediacy and Reference to Elite People
H9 NAIA ranked 5th worst airport in Asia: travel site Source: ABS-CBN News, Oct. 18,2016

H10 Massive protest action against Marcos burial set on Nov. 2 Source: GMA, Nov. 19, 2016

H11 Duterte curses Pope Francis over traffic during his visit Source: Rappler, November 30, 2015

H12 'No Duterte-Obama handshake at East Asia Summit'Source: ABS-CBN News, September 9, 2016

H13 Duterte wants kidnappers 'blown up,' even with hostages Source: Rappler, January 14, 2017

H14 Duterte hits Sereno Anew

Source: ABS-CBN, August 26, 2016

H23 Australian envoy boos Duterte's rape remark Source: ABS-CBN News, April 18, 2016

H24 Top Cebu 'drug lord' surrenders to Dela Rosa Source: Rappler Intensification,

H25 Duterte names politicians, cops, judges in drug trade Source: ABS-CBN News, Aug. 7, 2016
Evaluative Language (Superlative) and Reference to Continent

Vocabulary and Reference to Event

Vocabulary, Immediacy and Reference to Elite People

Vocabulary and Reference to Elite People and Event

Vocabulary, Immediacy and Reference to Elite People

Vocabulary, Immediacy and Reference to Elite People

Vocabulary, Immediacy References to Elite People and Role Label

Immediacy and References to Elite People and Role Label

Immediacy, References to Elite People and Role Labels 
Table 1. Continue....

\begin{tabular}{|c|c|c|c|}
\hline Headlines & Discursive Devices & Headlines & Discursive Devices \\
\hline $\begin{array}{l}\text { H18 Russia is planning for } \\
\text { low oil prices for years } \\
\text { Source: CNN Philippines, } \\
\text { Oct. } 14,2016\end{array}$ & $\begin{array}{l}\text { Immediacy and Reference } \\
\text { to Continent }\end{array}$ & $\begin{array}{l}\text { H26 Philippine Church } \\
\text { speaks out on drug killings } \\
\text { Source: ABS-CBN News, } \\
\text { Jan. 18, } 2017\end{array}$ & $\begin{array}{l}\text { Immediacy, Reference to } \\
\text { Institutionalized Agency }\end{array}$ \\
\hline $\begin{array}{l}\text { H17 Duterte eyeing visit } \\
\text { to Vatican because of 'pope } \\
\text { joke,' spokesman says } \\
\text { Source: GMA, May } 11 \text {, } \\
2016\end{array}$ & $\begin{array}{l}\text { Immediacy and Reference } \\
\text { to Elite People }\end{array}$ & $\begin{array}{l}\text { H27 Duterte calls US am- } \\
\text { bassador 'bakla' over cam- } \\
\text { paign comments Source: } \\
\text { GMA, August 5, } 2016\end{array}$ & $\begin{array}{l}\text { Vocabulary, Immediacy } \\
\text { and Referencse to Elite } \\
\text { People and Role Label }\end{array}$ \\
\hline $\begin{array}{l}\text { H18 Russia is planning for } \\
\text { low oil prices for years } \\
\text { Source: CNN Philippines, } \\
\text { Oct. } 14,2016\end{array}$ & $\begin{array}{l}\text { Immediacy and Reference } \\
\text { to Continent }\end{array}$ & $\begin{array}{l}\text { H28 De Lima: Duterte's } \\
\text { immunity is use- } \\
\text { less against Interna- } \\
\text { tional Criminal Court } \\
\text { Source:CNN Philippines, } \\
\text { Oct. 15, } 2016\end{array}$ & $\begin{array}{l}\text { Vocabulary, Reference to } \\
\text { Elite People and Interna- } \\
\text { tional Agency }\end{array}$ \\
\hline $\begin{array}{l}\text { H19 Cancer-stricken } \\
\text { Miriam in ICU Source: } \\
\text { ABS-CBN News, June 1, } \\
2016\end{array}$ & $\begin{array}{l}\text { Reference to Emotion and } \\
\text { Reference to Elite People }\end{array}$ & $\begin{array}{l}\text { H29 Who's winning in } \\
\text { Duterte-Roxas word war? } \\
\text { Source: Rappler, March 7, } \\
2016\end{array}$ & $\begin{array}{l}\text { Immediacy, Evaluative } \\
\text { Language (Interrogative), } \\
\text { Reference to Elite People, } \\
\text { and immediacy }\end{array}$ \\
\hline $\begin{array}{l}\text { H20 Baby dead, } 4 \text { injured } \\
\text { in Myanmar family suicide } \\
\text { attempt Source: TV5 Inter- } \\
\text { aksyon, January } 23,2017\end{array}$ & $\begin{array}{l}\text { Quantification and Refer- } \\
\text { ence to Emotion }\end{array}$ & $\begin{array}{l}\text { H30 Miss Universe corona- } \\
\text { tion generated } 34.6 \text { million } \\
\text { tweets worldwide Source: } \\
\text { Interaksyon, Feb. 4, } 2017\end{array}$ & $\begin{array}{l}\text { Quantification and Refer- } \\
\text { ence to Event }\end{array}$ \\
\hline $\begin{array}{l}\text { H21 10-year-old girl } \\
\text { raped, strangled using } \\
\text { her underwear Source: } \\
\text { ABSCBN News, Oct. 20, } \\
2016\end{array}$ & $\begin{array}{l}\text { Quantification and Refer- } \\
\text { ence to Emotion }\end{array}$ & & \\
\hline $\begin{array}{l}\text { H22 Albuera Mayor Es- } \\
\text { pinosa, } 1 \text { other inmate } \\
\text { killed in jail cell shootout } \\
\text { - CIDG Source: CNN } \\
\text { Philippines, Nov. } 17,2016\end{array}$ & $\begin{array}{l}\text { Quantification, Reference } \\
\text { to Emotion and Reference } \\
\text { to Elite People }\end{array}$ & & \\
\hline
\end{tabular}

The word "anti-Duterte" which means "opposed to Duterte" denotes negativity. When the said anti-Duterte advertisement campaign was shown on national TV by ABS-CBN and GMA networks, it caused negative reactions from the netizens, especially from the online supporters of Duterte. Also, the word "uproar" highlights the effect of the said advertisement on the viewers.

Moreover, the use of the simple present "causes" in the headline makes the issue new and fresher. Thus, it makes the headline eye-catching and interesting. As mentioned by Chovanec (2003), the key purpose for predominance of the present simple tense in news headlines results from the fact that the writer of the article attempts to convince potential readers that the information is brand new, even though it already happened in the past.

Another way to make the readers click the news article online is through the use of abstract or ambiguous terms like in headline 2, Bong Go "knocks out" Pacquiao. It shows two discursive devices: evaluative language, which in this context connotes ambiguity; and reference to elite people, which refers to Pacquiao. The phrasal verb "knocks out" becomes ambiguous because it implies several meanings. It could mean that a person or a thing is theatrically striking, appealing, or attractive. It could also refer to an inci- 
dence in which a match in boxing ends when a boxer has been knocked down by a hit and is incapable to start fighting again before 10 seconds have gone or it could mean causing someone to become unconscious.

However, Bong Go is not a boxer; instead, he is known by many as photo bomber and executive assistant of Duterte. Paquiao, on the other hand, is known as world champion in boxing. The intriguing part here that would make the readers read the entire news is, how did Bong Go knock out the boxing champion? One who can knock out Paquiao must be more expert and agile. Also, this reference to Paquiao makes the headline more attractive since Paquiao is a wellknown personality in the boxing arena. Besides, the headline is far from referring Bong Go to be striking or attractive. This could totally confuse the readers in interpreting the message, therefore, making them open the article and read to solve the puzzle.

A selection of concrete figures and statistics in the headline gives impression of providing readers with a credible account of the situation. The combination of evaluative vocabulary with a dose of numerical data is likely to engage readers both affectively and cognitively and, thus, capture their attention. Headline 3, Drilon fears 3-B aid from West put in jeopardy over Duterte 'insults', features two discursive devices. These are evaluative language in numerical form and references to elite people.

The figure " $3-\mathrm{B}$ " shows a huge amount of money referring to the aid from West. This is intensified by references to Drilon, who is a senator and Duterte, who is the president of the country which could be the recipient of the 3 billion dollars aid. Added to strengthen the effect of the issue are the words "fears" and "jeopardy". "Fear" means "an unpleasant emotion caused by being aware of danger, or a feeling of being afraid" while "jeopardy" means "danger". "Fears" also signals the use of simple present tense which emphasizes that the issue is brand new. Further, the cause is being emphasized in the headline through the adverb "over" referring to Duterte's insults. Moreover, the writer emphasizes in her headline the possible result of the insults which might influence the readers to put the blame on Duterte.

Also, in writing a headline, writers or editors often use modal verbs to draw readers' attention to click and read the news article. The term modality has been originally understood as the truth value of the proposition by logicians. In linguistics, modalities are considered as the structures that in one way or another evaluate the state of affair. In headline 4, Duterte: Binay and his family will go to jail if he fails, and 5 , China may give Filipino fishermen access to Scarborough, the writers did not only report the information but also of- fered their own attitudes about the events with the use of certain modal auxiliaries.

In headline 4, the writer quoting Duterte's words expressed his/her own prediction of the future event with the use of modal verb will. Reference to Binay and his family added an effect to the issue. It is emphasized that the ones who will be put in jail are not just any other persons but the vice president Binay and his family. In the same way, the writer in headline 5 expressed evidentiality that there is a realm of possibility through auxiliary modal may. It means that there is a possibility for Filipino fishermen to get access to Scarborough. The modal may expresses two possibilities: one that the fishermen can do fishing in the island or second, they cannot, depending on the outcome of something which is perceived here as the government's action to help the fishermen. Moreover, reference to China in the headline makes it appear that the Scarborough belongs to them when it has been claimed by our government as ours. This makes the issue even more controversial.

On the other hand, the evaluative parameter of necessity, also known as deontic modality, is realized by the use of modal verbs "must" and "should". The writers of the headline 6, Duterte: Obama must listen to me on human rights, and 7, Economist: govt should focus on crops other than rice, quoted the words said by Duterte and the economist. In addition, quoting what has been said suggests authenticity. The purpose of the writers here is to emphasize that certain course of actions, listening to me on human rights and focusing on crops should be taken through using the auxiliary modals must and should. The presence of references to elite person and role label, in this case, "Obama" and "economist", elevates the importance of the issues.

Furthermore, using superlatives is effective in headlines. They are often used by the writers and editors to grab the interest of the readers. In headline 8, Dev't aid 'highest ever' under Duterte - Dominguez, there are two discursive devices that are found. These are evaluative language (particularly the use of superlative) and reference to an elite personality. It is emphasized in the headline that under the presidency of Duterte, the amount of foreign development assistance is raised being the highest one. The positive superlative "highest" is used to describe the said raise. Highest as a superlative degree brings out comparisons of development aids granted by at least three presidents before Duterte's presidency. It is even more highlighted through the adverb "ever" which means that this did not happen before. Another device used in the headline that adds to the effect of sensationalism is the reference to Duterte who occupies the highest position in the government. Thus, readers' 
attention would be caught. However, in headline 9, NAIA ranked 5th worst airport in Asia: travel site contains the negative superlative "worst". This is a powerful device to draw the attention of the readers to open and read the article to find out what makes the airport "worst". In this case, it is used to describe the performance of NAIA according to a travel website. "Worst" implies another comparison, and this time, the Philippine airport is compared to not less than ten countries which have airports. Among those airports, NAIA ranked 5th. Montgomery (2007) emphasizes that with the use of negative vocabulary, surely, readers' attention may be caught because negativity has been determined as a top news value. He further added that sensationalist headlines utilize negatively charged terminologies, verbs that denote destructive or debilitative actions, pejorative adjectival modifiers, collocations, and negations that result in constructing negative connotations.

Another discursive device found in the headlines that can attract readers' attention is vocabulary or the choice of words used by the writers. The accumulation of intense vocabulary in the headline is likely to draw attention. Headline 10, Massive protest action against Marcos burial set on Nov. 2 , is a clear manifestation of this intense vocabulary using the phrase "massive protest" and the word "against". These words strengthen or sensationalize the objection of some people to bury Marcos in "Libingan ng mga Bayani". Also, the above-mentioned headline indicates that the writer not only presented the information about the event to happen but also expressed his or her own evaluation of the events through evaluative adjective "massive protest". The vocabulary "massive" describes a widespread action participated in by a large number of people who are coming from different places, which means that the protest is that big deal. Headline 11, Duterte curses Pope Francis over traffic during his visit, shows the use of discursive devices, such as vocabulary and references to elite people. The verb "curses" in the headline is a strong vocabulary that highlights the action done by Duterte toward Pope Francis during his papal visit in the Philippines. References to Duterte, the Philippine president, and Pope Francis, the highest authority in the Roman Catholic hierarchy, in the headline make the issue even more sensationalized. Thus, it makes it all the more attractive. This now brings out the attitude or ideology of the writer who obviously does it to either project an image as ill-mannered president or to arouse anger against the president. Whichever is the writer's intention, the headline implies the biased stance of the writer against Duterte. This may be done to influence or provoke the readers, especially those who support or are against Duterte.
In headline 12, 'No Duterte-Obama handshake at East Asia Summit', vocabulary and references to elite people are evident as discursive devices used by the writer/editor to call the attention of the consumers of the news. The word "no" in the headline which means "none" indicates negativity. It sharpens the idea that Obama snubbed Duterte or vice versa during the East Asia Summit in Laos. However, this report does not coincide with the Washington Post that says "Obama shook hands with Philippine President Rodrigo Duterte at a regional summit". This is a clear indication of twisting the news; thus, it shows writer's attitude towards the issue and further shows his/her political preference, and that is, Duterte as Philippine president makes an enemy out of the Philippine's prime ally, the United States, represented by the US president, Obama.

In headline 13, Duterte wants kidnappers 'blown up,' even with hostages, the importance of the issue is elevated through the use of vocabulary and by references to Duterte and his command. The transitive verb 'blown up' which means "to rend apart, shatter, or destroy" showcases negativity. It denotes a destructive action, in this case, an act of totally devastating the kidnappers' lives which can include the hostages' lives as well. Here, negativity is sustained or sensationalized with the use of the adverb "even" to stress that the said action is unlikely or questionable. The writer here is obviously against the 'blowing up' especially with hostages involved.

Headline 14, Duterte hits Sereno Anew, clearly manifests two discursive devices. These are the use of vocabulary and references to elite people. In the headline, references to Duterte and Sereno raise up the importance of the issue. The word "hit" is confusing. Its dictionary synonyms include strike, slap, and smack. These synonyms do not actually match to the content of the entire news. The writer here has an intention to mislead the netizens, especially that many of them only read the headline and not the entire news. In addition, the adverb "anew" which means "over again or once more" is another device that intensifies the topic. It indicates that Duterte does not only hit Sereno once but twice or even more. The writer wants to emphasize that Duterte has been doing it many times which is unlikely for the president, a man, to do to the Supreme Court justice, a woman, who should be respected by a man.

Furthermore, the role of intensifiers and quantifiers in sensationalizing the coverage should not be underestimated. With the use of intensifiers and quantifiers in the headlines, readers are more likely to be drawn to it. Also, people like predictability and don't like uncertainty that makes it the first reason why numbers work in headlines. Numbers pro- 
vide readers with expectation management, so they would know closely what they are getting into. Furthermore, it appears to be more interesting when the headline contains larger numbers.

Headline 15, Some 800,000 devotees join fluvial parade for Cebu's Sinulog Festival, features numerical references to number and event. The quantifiers "some" and "800,000" emphasize that there is a huge number of devotees who join the fluvial parade. Moreover, a reference to Sinulog Festival, which is a well-known festival in Cebu, helps the headline look more attractive, thus, could arouse the interest of the readers.

Furthermore, in headline 16, Advocacy group urges Duterte to sign anti-smoking EO soonest, the intensifier and references to elite organization and personality are apparent. The significance of the issue is promoted by reference to the advocacy group urging Duterte to sign the anti-smoking executive order. In addition, the adverb "soonest" is used as an intensifier. It intensifies the idea that the signing of the said executive order must be done quickly. This also brings out the desire of the writer to make the signing immediate. According to Molek-Kozakowska (2013), one added type that needs to be investigated with respect to its sensationalizing potential is the use of grammatical structure to mark recency and timeliness, or immediacy. Some sensational headlines derive their pressing character from the impression of urgency created with the use of the present progressive tense. The verbs "eyeing" and "planning" in headlines 17, Duterte eyeing visit to Vatican because of 'pope joke,' spokesman says, and 18, Russia is planning for low oil prices for years, are both in present progressive form. Their purpose is to make the news look fresh, more dramatic and immediate and although the action has not been completed as indicated by the ing form, there is a sense of continuing and progress. Also, references to Duterte, Vatican, and spokesman in headline 17 are added to make the issue catchier. While reference to Russia in headline 18 showcases the importance of the issue. It is reported that Russia is the second biggest oil exporter after Saudi Arabia. It indicates that Russia has been planning for low oil and that the relevance of the issue is fresher at the moment. "Has been planning" connotes an activity that may be realized or not realized in the immediate future. Thus, it makes it even more attractive for netizens to read the news.

Another discursive device that can sensationalize issues involves explicit references to emotions. These are attributed to either protagonists or readers, presumably to arouse affective reactions that prime attention. In headline 19, Cancer-stricken Miriam in ICU, there are two discursive de- vices that sensationalize the issue. These are reference to emotion and reference to an elite personality. The phrase "cancer-stricken" is undoubtedly a powerful adjective used by the writer to bring out emotions from the readers. The word "cancer" literally means "a serious disease caused by cells that are not normal and that can spread to one or many parts of the body" while the word "stricken" means "powerfully affected by disease, trouble, or sorrow". These meanings clearly show that the illness is no small. The emotion is sustained by reference to elite personality, the popular senator, Miriam Defensor Santiago, being in ICU which means that her situation was serious and severe which can stir emotions, especially to her followers. Molek-Kozakowska (2013) states that reference to emotion intrudes on readers' affective perception and activates feelings and moods that may then redirect attention, and makes it a powerful sensationalizing device used in the headlines by the media practitioners.

In the same vein, headline 20, Baby dead, 4 injured in Myanmar family suicide attempt, shows a more intense reference to emotion wherein readers would feel angry towards the agent who is intentionally dropped. The use of quantifier and reference to emotion are obvious. The adjective "dead" that refers to a baby is an intense word that may cause rage from the readers. It is because babies always have a soft spot in the hearts of netizens. Most likely, that alone can already make the issue sensational. Further, the quantifier " 4 " that refers to a number of injured family members during the suicide attempt intensifies even more the emotion that may redirect the readers' attention to click the article to know the real incident.

Furthermore, in headline 21, 10-year-old girl raped, strangled using her underwear, the writer uses the quantifier and reference to emotion as devices to attract attention. Like the headline 20 , headline 21 has the same effect on the audience. The use of verbs "raped" and "strangled" may impinge on readers' affective perception. In addition, the quantifier " 10 " that refers to the girl's age, which means that she is too young, raped, and strangled using her underwear, increases the rage and interest of the readers to read the entire news. Headline 22, Albuera Mayor Espinosa, 1 other inmate killed in jail cell shootout - CIDG, also displays quantifier and reference to emotion and elite personality. The verb "killed" calls for attention from the consumers to read the whole news because this word is too heavy not to be noticed. Also, reference to Albuera Mayor Epinosa is added to elevate the issue of shootout in jail cell since his name had been linked to illegal drug trade. Consequently, the use of quantifier " 1 " is used to emphasize that not only the mayor was killed but 
also another inmate. The writer here is trying to emphasize that the outcome of shootout does not only involve one person being killed but two. Quantification, specifically numerical data, is used by the writers in order to intensify the information that may lead the news consumers to read the whole article (Richardson, 2007).

Molek-Kozakowska (2013) states that references to elite people and institutional agents have long been known as instrumental in generating interest. News is often presented in relation to professional roles of participants: MPs, ministers, administrators, police chiefs, doctors, judges, professors, school headmasters, health inspectors, executives, spokespeople of various organizations. Headline 23, Australian envoy boos Duterte's rape remark, shows the use of vocabulary and references to an elite person and role label; this time, Duterte and Australian envoy. The headline talks about Duterte's rape remark. The word "boos" expresses the feeling of disapproval. Also, instead of writing the specific names, the role label, "Australian envoy" is used to emphasize the position of the agent and to stimulate responses from the readers. Using the specific name on the headline will create less impact and that readers might not recognize who this person is. Thus, role label is used, for the same reason, to sensationalize the issue. This is clearly done to generate gossips that he is not just any other person who is annoyed by Duterte's rape remark but the Australian envoy himself.

The same idea is evident in headlines 24,25 , and 26 . These three headlines are related to war on drugs. In headline 24 , Top Cebu 'drug lord' surrenders to Dela Rosa, the use of intensifier and two references are shown. One is reference to role label, "drug lord" and the other one is reference to an elite personality, "Dela Rosa". The role label "drug lord" is used to articulate higher impact because using his name on the headline will not magnetize the readers' attention. This is also strengthened by the use of the intensifier "top" which describes that this drug lord is no ordinary but the uppermost of his kind. In addition, reference to Dela Rosa is used for emphasis. This is because his name is more popular, especially when it comes to war on drugs. Thus, it would exert a pull on readers' interest.

In headline 25, Duterte names politicians, cops, judges in drug trade, Duterte, which is a clear reference to an elite personality, names those who are involved in the drug trade. These are the "politicians", "cops", and "judges" which are references to role labels. Furthermore, the fact that it was the first time in Philippine history that a president ever named politicians, cops, and judges involved in a drug trade is already sensational but these references draw the atten- tion of the readers even more to click the article to know who these persons are.

Likewise, in headline 26, Philippine Church speaks out on drug killings, the importance of the issue about drug killings is elevated by reference to institutional agency or group. The phrase "Philippine Church" is used as reference to institutionalized agency. This is to influence the readers' minds that it is not just a small church but the entire church in the Philippines that is against these drug killings, from the pope to the cardinals to the priests to the lay ministers. How the writer or editor feels about the issue is also manifested in the headline for they want to influence the readers into believing them.

In headline 27, Duterte calls US ambassador 'bakla' over campaign comments, the word "bakla" which means "sexually attracted to someone who is the same sex", referring to US ambassador highlights the significance of the issue. The word "bakla" here actually could mean that the ambassador has no balls or courage. Moreover, the word "over" emphasizes the reason of such name calling. The issue is also intensified by references to "Duterte" and the "US ambassador". This is intentionally done by the writer to stimulate and create different reactions from the readers, hence, pushing them to read content. The use of such institutionalized role labels, instead of precise names of persons, in headlines may be treated as a tool to increase readers' interest and make them seek closure with respect to presented stories (Althaus, Edy, \& Phalen, 2001).

While in headline 28, De Lima: Duterte's immunity is useless against International Criminal Court, the use of vocabulary, references to elite personality and agency are noticeable. The headline suggests that Duterte has no power over International Criminal Court. This also brings out the attitude or ideology of the writer by using the word of De Lima "useless" which means "of no use" to describe Duterte's immunity against ICC. This could mean that Duterte's influence is only effective in the Philippines where people, including the government officials, seemed intimidated by Duterte. Thus, it makes it appear Duterte being weak against the international court.

Moreover, to arouse the readers' curiosity to read what follows the headline, questions or interrogatives are used by the media practitioners. The writers themselves provide the answer within the article; that's why, such question headlines do not require answers on the part of the readers.

In headline 29, Who's winning in Duterte-Roxas word war?, there are three discursive devices found. These are evaluative language referring specifically interrogative and ref- 
erence to elite people, and immediacy. The interrogative "who" is used to arouse curiosity among readers. References to "Duterte" and "Roxas" emphasize that the persons involved in the word war are popular and controversial while the present progressive tense "is winning", which connotes a continuing action, highlights the impression of urgency that may push readers to click the answer in the article.

Headline 30, Miss Universe coronation generated 34.6 million tweets worldwide, possesses the discursive devices, quantifier and reference to event. The reference to Miss Universe Coronation, which is a world-wide event, is highlighted since it has just happened days ago and it is still fresh. Readers are still on hype about its result. Furthermore, the quantifier "34.6 million" gives emphasis to number of tweets generated from the twitter alone. It indicates that it is by far the highest tweet volume for an entertainment event during the live show. This also means that a huge number of people is monitoring or viewing it or interested in it. Hence, it may make the readers click and read the entire article.

\section{Ideologies of Media Practitioners Reflected in Head- lines}

In this part of the study, a critical discourse analysis of the headlines is made. This is to answer the second question of this study. It focuses on the ideologies of media practitioners reflected in the headlines.

Moreover, CDA views all language as creating an ideology of sorts and is concerned with revealing and scrutinizing those concealed agendas in language that may be ideological. Ideology mainly refers to the sets of beliefs, attitudes, and values which may form both groups' and individuals' perceptions (Taiwo, 2007).

Table 2 shows different ideologies of media practitioners reflected in the headlines.

TABLE 2. Ideologies of media practitioners

\begin{tabular}{ll}
\hline \hline Ideologies & Headlines \\
\hline Neutral or objective & H4 Duterte: Binay and his family will go to jail if he fails Source: CNN Philippines, April 9, 2016 \\
& H7 Economist: govt should focus on crops other than rice Source: Interaksyon, Jan. 23, 2017 \\
& H8 Dev't aid 'highest ever' under Duterte - Dominguez \\
& Source: Rappler, January 15, 2017 \\
& NAIA ranked 5th worst airport in Asia: travel site Source: ABS-CBN News, Oct. 18, 2016 \\
& H17 Duterte eyeing visit to Vatican because of 'pope joke,' spokesman says \\
& Source: GMA, May 11, 2016 \\
& H20 Baby dead, 4 injured in Myanmar family suicide attempt Source: TV5 Interaksyon, January \\
& 23,2017 \\
& H30 Miss Universe coronation generated 34.6 million tweets worldwide \\
& Source Interaksyon, Feb. 4, 2017 \\
& H3 Drilon fears 3-B aid from West put in jeopardy over Duterte 'insults' \\
& Source: GMA, October 12, 2016 \\
& H10 Massive protest action against Marcos burial set on Nov. 2 \\
& Source: GMA, Nov. 19, 2016 \\
& H13 Duterte wants kidnappers 'blown up,' even with hostages Source: Rappler, January 14, \\
& 2017 \\
& H23 Australian envoy boos Duterte's rape remark \\
& Source: ABS-CBN News, April 18, 2016 \\
& H14 Duterte hits Sereno Anew Source: ABS-CBN, August 26, 2016 \\
& H2 Bong Go "knocks out" Pacquiao Source: ABS-CBN News, Dec.15, 2016 \\
\hline \hline
\end{tabular}

Reflected in Table 2 are the ideologies of media practitioners evident in the headlines. It is an old convention in journalistic writing that objectivity in news is a must. It is in this reason why some news writers or editors are trying to make their headlines appear balanced or impartial. This is evident in H4, H7, H8, H9, H17, H20 and H30.

In headlines Duterte: Binay and his family will go to jail if he fails Source: CNN Philippines, April 9, 2016

In headlines Economist: Govt should focus on crops other than rice Source: Interaksyon, Jan. 23, 2017 
H8 Dev't aid 'highest ever' under Duterte - Dominguez Source: Rappler, January 15, 2017

H9 NAIA ranked 5th worst airport in Asia: travel site Source: ABS-CBN News, Oct. 18, 2016

H17 Duterte eyeing visit to Vatican because of 'pope joke,' spokesman says Source: GMA, May 11, 2016 H20

H20 Baby dead, 4 injured in Myanmar family suicide attempt Source: TV5 Interaksyon, January 23, 2017

H30 Miss Universe coronation generated 34.6 million tweets worldwide Source: Interaksyon, Feb. 4, 2017

Headlines 4, 7, 8, 9, and 17 show direct and indirect speech. Writers are merely showing other people's statements and comments without committing to the truth of utterance. In other words, writers are able to demonstrate preservation of objectivity by echoing someone else's words in their headlines.

In the same vein, $\mathrm{H} 20$ and $\mathrm{H} 30$ illustrate neutrality. The news practitioners here are said to be neutral through the use of numbers 4 and 34.6 million. The use of these numbers or figures indicates precision in news writing, thus, making the writers or editors appear to be unbiased or objective Tuchman (1978) and Van Dijk (2013).

However, there are media practitioners who tend to involve their opinion in writing headlines. News stories are supposed to be impartial and non-partisan. But there are writers or editors who tend to be biased or subjective. Lerner (1992) defined media bias as a kind of prejudice in news and media reports which is perceived as an unfair or imbalanced presentation of information or selective reporting of which events or facts are reported. Along this line, SarfoAdu, et al. (2015) say some journalists and news producers in the mass media choose only the events and stories they think are fitted, and decide to write or report them to suit their ideological or political predisposition. This is manifested in H13, H10, H13, and H23.

H3 Drilon fears 3-B aid from West put in jeopardy over Duterte 'insults' Source: GMA, October 12, 2016

H10 Massive protest action against Marcos burial set on Nov. 2 Source: GMA, Nov. 19, 2016

H13 Duterte wants kidnappers 'blown up,' even with hostages Source: Rappler, January 14, 2017

H23 Australian envoy boos Duterte's rape remark Source: ABS-CBN News, April 18, 2016

These headlines exhibit bias or subjectivity. In H3, impartiality is evident through the use of the words fears and jeopardy. The writer could have used the word "worries" instead of fears and "trouble" instead of jeopardy to avoid partiality. In $\mathrm{H} 10$, the protest is highlighted through the use of the adjective massive. It is even given more impor- tance through thematization of the phrase massive protest to strengthen the idea that the protest will involve many people; not just hundreds but thousands perhaps. Massive also shows the inclination of the writer towards the protesters by trying to depict an extensive participation of protesters. In this case, the writer is lightly biased for she could have written the exact number of people who are going to attend the protest instead of using the word massive. In the same light, $\mathrm{H} 2$ shows ideology of the writer or editor as biased.

Duterte is used as the agent of the action who wants to emphasize that it was he who ordered the action blown up to be done. It is also emphasized through the use of the adverb even to show that such act sweepingly includes the hostages. Moreover, the use of the verb blown up is added to the effect of the writer's partiality. A more neutral choice for it would have been attack. The writer here, in one way or another, wants the readers to put the blame on Duterte. Also, H23 puts emphasis on the Australian envoy who does the booing. It serves as the agent which is being thematized. The Australian envoy here appears to be more powerful than Duterte who was then running for president. Furthermore, the verb boos in the headline stresses the attitude of the writer as biased towards the issue. The writer could have used the more neutral word like disapproves or criticizes instead of boos. In this study, subjectivity or bias is revealed through word choice. Egbeyemi (2014) maintains that one of the many biases that journalists employ to influence opinions and perceptions is through bias by word choice. For example, Duzett (2011) states that to subtly convey bias, word choice is a key tool that a reporter or writer can use. In other words, Pajunen (2008) posits in news report or news writing, the choice of words is of great value for they convey diverse shades of meaning, thus determining which words or terms to utilize in a news headline is significant. As he simply puts it, there are always various ways to word events, people, and phenomena.

In addition, there are headlines that are misleading. Writers or editors here tend to mislead readers by making them believe into something the way they want them to see the issue. Online news is now often driven by the quest for page views instead of the quest for truth. One indication of this alteration is a propagation of clickbait headlines. Clickbait refers to the content whose core aim is to entice and encourage readers to click on a link of a certain web page. Headlines that are unverified, misleading, and seldom corrected are the major contributors to the wide-spread of fake news on the internet (Silverman, 2015).

$\mathrm{H} 2$ and $\mathrm{H} 3$ are both misleading. 
H2 Bong Go "knocks out" Pacquiao Source: ABS-CBN News, Dec.15, 2016

H14 Duterte hits Sereno Anew Source: ABS-CBN, August 26, 2016

In H2, Bong Go is the agent who does the action knocks out while Paquiao is the receiver of such action. It is misleading since everyone knows Bong Go as Duterte's executive assistant but never a boxing personality. The thought of him knocking out Paquiao is unbelievable because Paquiao is known to be The People's Champ in the boxing field. The readers might wonder how in the world Bong Go knocked out Paquiao. In the same vein, $\mathrm{H} 14$ has also a misleading message. The dictionary meaning of hit is to move your hand, a bat, etc., rapidly so that it touches someone or something in a strong or vehement way. It does not fit to the content of the article which says "Duterte... lectured Sereno on the validity of warrantless arrest". The writer could have used the word lecture instead of hit to match to its content. It is implied in the Gricean maxims of communication that readers assume that a headline is relevant and truthful in relation to its article. However, headlines can, therefore, be misleading if there is a misrepresentation of the gist of an article (Althaus et al., 2001).

\section{Insights that can be Generated from the Findings}

After reading and analyzing the thirty headlines from the five famous online news portals in the Philippines, the following insights can be generated:

Firstly, writers or editors use discursive devices in headlines not just to catch the interest of the readers but to push them to read the entire article.

Secondly, there are headlines that are misleading. Sometimes, casual readers may be deceived by this. That is why, an in-depth analysis or exploration of the headline message is needed in order to understand the real content of the news.

Thirdly, the writers' or editors' ideologies or attitudes toward the issues are exposed. They tend to be neutral or biased depending on the issue presented.

Lastly, headlines are loaded with discursive devices and linguistic devices which can be a good focus for any form of textual analysis or linguistic analysis.

\section{CONCLUSION}

This study focused on the analysis of thirty headlines from five major online news portals in the Philippines. Discursive or sensationalizing devices used by media practitioners in the headlines are revealed. These are the evaluative language, vocabulary, intensification and quantification, reference to emotion, reference to elite people, role labels, agency, country, and events. In addition, this study investigated the ideologies of media practitioners reflected in the headlines. Some are neutral or objective, biased or subjective, and some are misleading.

\section{LIMITATIONS AND RECOMMENDATIONS}

This study also revealed some insights generated from the findings of the study. Based on the results, the following are recommended: a similar study may be conducted using another tool like transitivity and nominalization; while this study centered on the online news portals, other researchers may use additional or other means in getting headlines like newspaper, television, and radio; since the focus of this study was on headlines, future researchers may have the entire article to analyze, to expose, and to view the style of the writer and the value of the content of the article; and they may also focus on both the headline and its content to really see the difference, if they match or not.

\section{REFERENCES}

Althaus, S. L., Edy, J. A., \& Phalen, P. F. (2001). Using substitutes for full-text news stories in content analysis: Which text is best? American Journal of Political Science, 4(5), 707-723.

Bonyadi, A., \& Samuel, M. (2013). Headlines in newspaper editorials: A contrastive study. Sage Open, 3(2), 21-34. doi: https://doi.org/10.1177/2158244013494863

Brandenstein, D. E. (1911). Sensational and political headlines: an exploration of front-page headlines (Unpublished Phd thesis). Department of Arts and Letters, San Diego State University, San Diego, California.

Chovanec, J. (2003). The mixing of modes as a means of resolving the tension between involvement and detachment in news headlines. Brno studies in English, 29(1), 1-9. doi:https://doi.org/10.5817/bse2012-2-1

Conboy, M. (2013). The language of the news. Englang, UK: Routledge.

Duzett, A. (2011). Media bias in strategic word choice. Retrieved from https : //goo.gl/JHYb62 (accessed on 17 May 2017)

Egbeyemi, A. (2014). Bias by word choice and tone. Retrieved from https://goo.gl/Cbjrjf (accessed on 16 October 2017)

Fairclough, N. (1992). Discourse and social change (Vol. 10). England, UK: Polity Press Cambridge. 
Fairclough, N. (2001). Critical discourse analysis as a method in social scientific research. Methods of critical discourse analysis, 5(11), 121-138. doi:https://doi.org/10.4135/9780857028020.n6

Fairclough, N., \& Wodak, R. (1995). Critical discourse analysis. New York, NY: John and Willy Sons.

Grabe, M. E., Zhou, S., \& Barnett, B. (2001). Explicating sensationalism in television news: Content and the bells and whistles of form. Journal of Broadcasting \& Electronic Media, 45(4), 635-655. doi:https://doi.org/10.1207/ s15506878jobem4504_6

Javed, S., \& Mahmood, R. (2011). A critical discourse analysis of the news headlines of budget of Pakistan. Interdisciplinary Journal of Contemporary Research in Business, 3(5), 120-129.

Kang, C. Z., \& Ogawa, I. (2017). Online shopping behavior of chinese and Japanese consumers. Journal of Administrative and Business Studies, 3(6), 305-316. doi:https://doi.org/10.20474/jabs-3.6.5

Lerner, G. (1992). Black women in white america: A documentary history. New York, NY: Vintage.

Luke, A., Freebody, P., et al. (1997). Shaping the social practices of reading. Constructing Critical Literacies: Teaching and Learning Textual Practice, 6(6), 460-475. doi:https://doi.org/10.4324/9780203840412.ch19

Metila, R. A. (2013). A discourse analysis of news headlines: Diverse framings for a hostage-taking event. Asian Journal of Social Sciences and Humanities, 2(2), 71-78. doi:https://doi.org/10.17501/icedu.2016.1106

Molek-Kozakowska, K. (2013). Towards a pragma-linguistic framework for the study of sensationalism in news headlines. Discourse \& Communication, 7(2), 173-197. doi:https://doi.org/10.1177/1750481312471668

Montgomery, M. (2007). The discourse of broadcast news: A linguistic approach. London, UK: Routledge.

Oetomo, H. W., lestariningsih, M., \& Susanti. (2017). Spatial analysis of newspaper sales in east surabaya traffic lights using moran index. International Journal of Business and Administrative Studies, 3(5), 166-174. doi:https://doi.org/ 10.20469/ijbas.3.10002-5

Pajunen, J. (2008). Linguistic analysis of newspaper discourse in theory and practice (Tech. Rep.). University of Tampere, Tampere, Finland.

Prateepchaikul, N. (2010). Headline writing techniques in general news articles (Unpublished master's thesis). Srinakharinwirot University, Bangkok, Thailand.

Reah, D. (2002). The language of newspapers. London, UK: Psychology Press Routledge.

Richardson, J. E. (2007). Analysing newspapers; an approach from critical discourse analysis. New York, NY: Palgrave Macmillan.

Silverman, C. (2015). Lies, damn lies, and viral content: How news websites spread (and debunk) online rumors, unverified claims and misinformation. Tow Center for Digital Journalism, 168(4), 134-140.

Taiwo, R. (2007). Language, ideology and power relations in Nigerian newspaper headlines. Nebula, 4(1), 34-45. doi: https://doi.org/10.4018/978-1-61520-827-2.ch010

Tannen, D., Hamilton, H. E., \& Schiffrin, D. (2015). The handbook of discourse analysis. New York: John Wiley \& Sons.

Tuchman, G. (1978). News making: A study in the construction of reality. New York, NY: The Free Press.

Van Dijk, T. A. (2013). News analysis: Case studies of international and national news in the press. New Jersy, NJ: Routledge.

Yasmeen, K., Mahmood, M. A., Mahmood, R., Shakir, A., \& Sattar, A. (2014). A critical discourse analysis of newsworthiness in english and urdu newspaper headlines in Pakistan. New Media and Mass Communication(24), 60-64. 